\footnotetext{
${ }^{1}$ Institut für Tierzucht und Tierhaltung, Christian-Albrechts-Universität Kiel, Germany

${ }^{2}$ Forschungsinstitut für die Biologie landwirtschaftlicher Nutztiere, Dummerstorf, Germany

${ }^{3}$ Schaumann Forschungszentrum Hülsenberg, Wahlstedt, Germany
}

\author{
SEBASTEAN SCHWARZ ${ }^{1}$, ULRICH PRESUHN ${ }^{3}$, ERNST KALM ${ }^{1}$ \\ and NORBERT REINSCH ${ }^{1,2}$
}

\title{
Characterizing polymorphism and multiplex feasibility of 142 microsatellite markers from a commercial German Landrace line (short communication)
}

Dedicated to Prof. Dr. Peter Horst on the occasion of his $75^{\text {th }}$ birthday

\begin{abstract}
In using microsatellites to perform linkage studies or parentage testing in pigs the effectiveness of genotyping can substantially be enhanced by multiplex polymerase chain reactions (PCR), i.e. joint amplification of several microsatellites. However, and in contrast to other species, little has been published on specific multiplex sets of porcine microsatellites and their amplification conditions. As a by-product of a whole genome scan in purebred Landrace families we present information on 142 porcine microsatellites, covering all chromosomes with an average marker spacing of $15 \mathrm{cM}$. In total 96 of these markers were amplified in 45 different multiplex sets (duplex and triplex reactions) and 46 markers were amplified alone. Details of PCR conditions, observed fragment lengths in Landrace and allele frequencies are given and it is shown in detail, which microsatellites have been combined together. These informations may serve as an aid for the development of more complex multiplex sets, comprising a higher number of simultaneously amplified microsatellites.
\end{abstract}

Key Words: multiplex PCR, genetic polymorphism, microsatellites, sus scrofa, landrace

\section{Zusammenfassung}

Titel der Arbeit: Charakterisierung des Polymorphismus und der Multiplex-Eignung von 142 Mikrosatelliten in einer kommerziell genutzten Linie der Deutschen Landrasse (Kurzmitteilung)

Bei der Verwendung von Mikrosatelliten für Kopplungsanalysen und Abstammungsüberprüfungen kann der Genotypisierungsaufwand durch Multiplex-PCR (gemeinsame Amplifikation mehrerer Mikrosatelliten) deutlich gemindert werden. Bisher liegen jedoch kaum veröffentlichte Informationen über die Zusammenstellung von geeigneten Mikrosatelliten des Schweins für die Multiplex-PCR und die zugehörigen Reaktionsbedingungen vor. Als Nebenprodukt einer das gesamte Genom abdeckenden Kopplungsanalyse ergaben sich Informationen zu 142 Mikrosatelliten mit einem durchschnittlichen Markerabstand von 15cM. Insgesamt 96 dieser Marker ließen sich in 45 Multiplex-Reaktionen (zwei- und dreifach) amplifizieren, 46 Marker wurden einzeln amplifiziert. Die PCR-Bedingungen sowie die beobachteten Allelgrößen und Allelfrequenzen in der untersuchten Landrasse-Linie werden angegeben und es wird gezeigt, welche Mikrosatelliten miteinander kombiniert wurden. Diese Ergebnisse können als Ausgangspunkt für die Entwicklung komplexerer Multiplex-Reaktionen mit einer höheren Anzahl von Mikrosatelliten dienen.

Schlüsselwörter: Multiplex-PCR, genetischer Polyphormismus, Mikrosatelliten, Sus Scrofa, Landrasse

\section{Introduction}

In most mapping experiments in pigs crosses between different breeds have been used. Naturally, the polymorphism of microsatellites is expected to be larger in such crosses, compared to purebred strains. Microsatellite markers with satisfactory degree of polymorphism within a single line are however needed for certain mapping experiments as well as for the purpose of parentage testing.

ROHRER et al. (1997) described the advantages of multiplexing microsatellites reducing time and cost by amplifying a larger number of microsatellites 
simultaneously. Two marker sets have been previously developed, combining ten and five microsatellites for parentage testing in pigs (NECHTELBERGER et al., 2001). However, in contrast to other species (e.g. canine microsatellite markers, CARGILL et al., 2002) little has been published about multiplexing microsatellites in pigs. The same is true for the number and frequency of alleles occuring in purebreed lines or breeds of sus scrofa.

As a by-product of a mapping experiment we have charaterised a Landrace line for 142 microsatellite markers by genotyping 100 sows and boars from a commercial nucleus herd. This paper provides detailed information on the polymorphism and multiplex feasibility of these markers.

\section{Material and methods}

Eight paternal half-sib families (8 boars and 92 sows with 246 offspring) from a commercial purebred German Landrace nucleus herd were selected for genotyping. DNA was extracted from ear notches of the sows with the Puregene DNA Isolation Kit (Gentra Systems, USA). To isolate the DNA from sperm of the boars a modified protocol as described by XU (1997) was applied. After isolation genomic DNA concentration was adjusted to $40 \mathrm{ng} / \mu \mathrm{l}$ for the working solution and templates were dehumidified for conservation.

One hundred and fourty-two microsatellite markers covering all chromosomes were chosen from previously published maps. Polymerase chain reaction (PCR) amplification was performed in a $10 \mu$ reaction volume, which included 10-50 pmols of each primer, $200 \mu \mathrm{M}$ each dNTP, 1x PCR buffer (including $10 \mathrm{mM}$ Tris- $\mathrm{HCl}$ [ph 9.0], $50 \mathrm{mM} \mathrm{KCl}, 1.5 \mathrm{mM} \mathrm{MgCl}_{2}$ ) and 0.2-0.4 units Taq-Polymerase (Pharmacia, Germany). Amount of primer, buffer and Taq-Polymerase for polymerase chain reaction (PCR) are given by SCHWARZ (2003) for each marker. The 5 '-end of each forward primer was labeled with one of three fluorescent dyes: 6FAM, HEX, TET (Applied Biosystems Inc., USA). Amplification of fragments was finished in 96-well plates using an Biometra UNO II thermocycler (Biometra, Germany). PCR started with $94^{\circ} \mathrm{C}$ for 3 min followed by a marker-specific number of cycles, i.e. $20 \mathrm{sec}$ at $94^{\circ} \mathrm{C}$, annealing at a marker specific temperature $\left(50-65^{\circ} \mathrm{C}\right)$ and extension at $72^{\circ} \mathrm{C}$ for 30 sec. The marker-specific number of cycles varied from 30 to 42 followed by a final extension for $5 \mathrm{~min}$ at $72^{\circ} \mathrm{C}$. Alleles were separated on an ABI 377 Sequencer (Applied Biosystems Inc., USA) after combining up to seven microsatellites from four PCR reactions together.

Genotypes were stored in the ADRDB database (REINSCH, 1999) and were checked for consistency with the mendelian laws of inheritance using the GENCHECK program (BENNEWITZ et al., 2002). Allele frequencies and degree of observed heterozygosity were calculated with SAS programs from the genotypes of boars and sows.

\section{Results}

A set of 39 duplex and 6 triplex reactions was obtained. All triplex reactions were single-colour with the same dye (6FAM or HEX or TET) within every multiplex set. The microsatellites of these triplex reactions were located on eight different chromosomes. Nine single-colour duplex sets were each labelled with the dyes TET and HEX and 16 duplex reactions were 6FAM labeled. The five remaining duplex sets 
had different dyes within the set. Duplexed markers were spread across the whole genome. A residual of 46 markers was left for individual amplification in order to limit the effort for establishing multiplex reactions.

The number of alleles per microsatellite ranged from 2 to 11 with an average of 5.2. The degree of heterozygosity $\left(\mathrm{H}_{\mathrm{b}}\right)$ of sires and dams ranged from 0.06 to 0.89 with a mean of 0.59. Null alleles were not observed. The chromosomal assignment of all markers was well in agreement with previously published maps with one exception on Sscr 11 (own data: S0230-Sw435). Full details are displayed in SCHWARZ, 2003 (tables 7 and 8, pages 56-61; tables A1-A4, pages 158-173; freely accessible under http://e-diss.uni-kiel.de/diss_827/).

\section{Discussion}

To compile multiplex sets with more than three markers from scratch is costly and time-consuming. ROHRER et al. (1997) therefore recommended the use of up to three microsatellites. Larger sets may however be assembled from published double or triple multiplex sets. This of course requires an extra effort to verify the compatibility of the members of such large sets for PCR amplification and allele separation, but especially frequent users may nevertheless capitalize on informations about multiplex feasability. Hopefully multiplexing of porcine microsatellite markers for whole-genome screens will become easier in the future - as it obviously already is in other species (CARGILL et al., 2002) - by publishing more results on this subject.

Parentage testing is perhaps the most important and common field of application for large multiplex sets (NECHTELBERGER et al., 2001). Though multiplex feasibility of microsatellite markers is a useful technical feature for this purpose, it is far more important to select markers with a high degree of polymorphism in order to achieve a high probability for an exclusion of false parentages. The average number of identified alleles per microsatellite was however only 5.2 compared to an average of 8.8 alleles reported in the USDA-MARC database (URL 1) for the same microsatellites. As anticipated it turned out to be much more difficult to identify polymorphic microsatellites in our purebred line than in crossbreeds. Two experiments with crossbreds described by RUDAT (1997) and by FABUEL PEÑALVER (1999) may be taken as a comparison: a degree of heterozygosity of 0.72 and 0.76 was observed, respectively, which is considerably higher than the observed $\mathrm{H}_{\mathrm{b}}$ of 0.59 in our purebred line. The estimated allele frequencies give useful information for choosing markers for parentage testing and also for further mapping experiments in this particular line. For parentage control a set of 10 microsatellite markers has been recommended (NECHTELBERGER et al., 2001) for general use. Four of these markers were also represented in this study: S0090, S0101, S0355 and Sw951. However the respective numbers of observed alleles were only 4, 3, 3, and 3. For improved parentage testing especially in problematic cases with one unknown parent we recommend the marker loci S0097, S0105, S0106, S0230, Sw129, Sw344, Sw1808, Sw2441, Sw2517 and Swr1101 because of their high number of alleles with roughly equal allele frequencies.

\section{Acknowledgements}

The authors gratefully acknowledge support from the pigbreeding unit of the Schaumann Research Centre GmbH \& Co. KG. This work was supported by the 
"Förderverein Biotechnologieforschung der Deutschen Schweineproduktion e.V." (FBF).

\section{References}

BENNEWITZ, J.; REINSCH, N.; KALM, E.:

GENCHECK: A programm for consistency checking and derivation of genotypes at co-dominant loci. Journal of Animal Breeding and Genetics 119 (2002), 350-360

CARGILL, E. J.; CLARK, L.A.; STEINER, J. M.; MURPHY, K. E.:

Multiplexing of canine microsatellite markers for whole-genome screens. Genomics 80 (2002) 3, 250253

FABUEL PEÑALVER, E.:

Kartierung von QTL in einer Fünfrassenkreuzung beim Schwein. Schriftenreihe des Institut für Tierzucht und Tierhaltung der Christian-Albrechts-Universität zu Kiel (1999) Heft 115

NECHTELBERGER, D.; KALTWASSER, C.; STUR, I.; MEYER J.-N.; BREM, G.; MUELLER, M.; MUELLER, S.:

DNA microsatellite analysis for parentage control in Austrian pigs. Animal Biotechnology 12 (2001) 2, $141-144$

REINSCH, N.:

A multiple-species, multiple-project database for genotypes at codominant loci. Journal of Animal Breeding and Genetics 116 (1999), 425-435

ROHRER, G. A.; VOGELI, P.; STRANZINGER, G.; ALEXANDER, L. J.; BEATTIE, C. W.:

Mapping 28 erythrocyte antigen, plasma protein and enzyme polymorphisms using a efficient genomic RUDAT, I.: scan of the porcine genome. Animal Genetics 28 (1997) 5, 323-330

Kartierung des $R N$-Gens beim Schwein. Schriftenreihe des Institutes für Tierzucht und Tierhaltung der Christian-Albrechts-Universität zu Kiel (1997) Heft 97

SCHWARZ, S.:

Kartierung von Loci für kongenitales Ausgrätschen beim neugeborenen Ferkel. Schriftenreihe des Instituts für Tierzucht und Tierhaltung der Christian-Albrechts-Universität zu Kiel (2003) Heft 135

URL 1, 2003:

US Meat Animal Research Center, Clay Center, Nebraska, USA

$\mathrm{XU}, \mathrm{N}$.:

http://www.genome.iastate.edu/maps/marcmap.html

Markerkarten für acht Chromosomen und erste QTL-Analyse an deutschen Milchrinder-Familien. Schriftenreihe des Instituts für Tierzucht und Tierhaltung der Christian-Albrechts-Universität zu Kiel (1997) Heft 135

Received: 2005-04-18

Accepted: 2005-09-14

Authors' addresses

Dr. SEBASTEAN SCHWARZ, Prof. Dr. ERNST KALM

Institut für Tierzucht und Tierhaltung der Christian-Albrechts-Universität Kiel

Olshausenstr. 40

24098 KIEL / GERMANY

PD Dr. NORBERT REINSCH*

FB Genetik und Biometrie

FBN Dummerstorf

Wilhelm-Stahl-Allee 2

18196 DUMMERSTORF / GERMANY

Dr. ULRICH PRESUHN

Schaumann Forschungszentrum Hülsenberg

23812 WAHLSTEDT / GERMANY

*Corresponding author

E-mail: reinsch@fbn-dummerstorf.de 